Jurnal Akuakultur Sungai dan Danau Vol.1 No. 1 Tahun 2016 Hal 44 - 52

ISSN Online $2503-4766$

\title{
EFEKTIFITAS BIODEKOMPOSER SAAT PENGANGKUTAN IKAN LELE SANGKURIANG (Clarias. gariepinus Var. Sangkuriang ) DENGAN KEPADATAN TINGGI PADA TRANSPORTASI TERTUTUP UNTUK KEBUTUHAN BUDIDAYA
}

\author{
Sunardi $^{*}$, Syahrizal ${ }^{2}$, Zainal Arifin ${ }^{3}$ \\ Alumni Program Studi Budidaya Perairan ${ }^{1}$, Dosen Program Studi Budidaya \\ Perairan $^{2}$, Staf BAPPEDA Propinsi Jambi ${ }^{3}$ \\ Program Studi Budidaya Perairan, Fakultas Pertanian, Universitas Batanghari \\ Jalan Slamet Riyadi, Broni, Jambi 3612236122, Telp. +62074160103 \\ *email korespondensi: sunardi.bdp@gmail.com
}

\begin{abstract}
Abstrack
The process of transporting the seed often led to a decline in the quality and performance of the seed. The presence of fish during transport of metabolic processes led to a decline in water quality mainly an increase in ammonia (NH3) is also a factor that causes the occurrence of stress and death. Biodekomposer able to maintain water quality, therefore the necessary research on the usage of Biodekomposer in the process of transport of seeds of catfish in 2 liters of water in a sealed bag. The design of the study was a randomized Complete Design with 5 treatments and 3 replicates, such treatment is A Treatment: seed: catfish tail/100 l water, $b$ : seeds catfish tail/200 liters of water, C: seed catfish tail/400 liters of water, D: seed catfish tail/600 liters of water, each 10 grams of biodekomposer entered treatment in the media. K: seed treatment catfish tail/100 liters of water without biodekomposer. The results showed that the survival rate between different treatment real $(P 0.5 \%)$ with graduation < life the highest on treatment $A(91,17 \%)$ and $B(85,87 \%)$ the lowest treatment $D$ and $K$ respectively of 25.56 $18.58 \%$ and\%. These fish are living in the water quality of the initial temperature rataan 27, 05oC; $7.01 \mathrm{Ph}$; DO 5.0 ppm; 0.18 ppm of CO2 and Ammonia 0.0453 ppm. Kualiatas water after arriving at your destination with a travel time of 8 hours has decreased from the treatment A-D and K temperature 25.05 - $26.50 \mathrm{oC}$; $\mathrm{pH}$ 6.60-6.01; DO-3.56 out $2.50 \mathrm{ppm}$; CO2 0,610.78 ppm and 0,0508-moniak 0,087 ppm.
\end{abstract}

Keywords: Biodekomposer, transport, sangkuriang catfish

\begin{abstract}
Abstrak
Proses pengangkutan benih sering menyebabkan terjadinya penurunan kualitas dan peforma benih. Adanya proses metabolisme ikan selama pengangkutan menyebabkan terjadinya penurunan kualitas air terutama peningkatan ammonia (NH3) juga merupakan faktor yang menyebabkan terjadinya stres dan kematian. Biodekomposer mampu menjaga kualitas air, oleh sebab itu diperlukan penelitian tentang pengunaan Biodekomposer pada proses transportasi benih ikan lele dalam 2 liter air dalam kantong tertutup. Rancangan penelitian adalah Rancangan Acak Lengkap dengan 5 perlakuan dan 3 ulangan, perlakuan tersebut adalah: Perlakuan A: benih ikan lele 100 ekor/l air, B: benih ikan lele 200 ekor/liter air, C: benih ikan lele 400 ekor/liter air, D: benih ikan lele 600 ekor/liter air, masing-masing perlakuan dimasukan 10 gram biodekomposer dalam media air. Perlakuan K: benih ikan lele 100 ekor/liter air tanpa biodekomposer. Hasil penelitian menunjukkan bahwa tingkat kelangsungan hidup antar perlakuan berbeda nyata $(\mathrm{P}<0,5 \%)$ dengan kelulusan hidup tertingi pada perlakuan $\mathrm{A}$ $(91,17 \%)$ dan B $(85,87 \%)$ yang terendah pada perlakuan $\mathrm{D}$ dan $\mathrm{K}$ masing-masing sebesar $25,56 \%$ dan $18,58 \%$. Ikan ini hidup berada dalam kualitas air awal pada suhu rataan $27,05^{\circ} \mathrm{C}$; pH 7,01; DO 5,0 ppm; $\mathrm{CO}_{2}$ 0,18 ppm dan Amoniak 0,0453 ppm. Kualiatas air setelah sampai di
\end{abstract}


Jurnal Akuakultur Sungai dan Danau Vol.1 No. 1 Tahun 2016 Hal 44 - 52

ISSN Online 2503 - 4766

tujuan dengan lama perjalanan 8 jam mengalami penurunan dari perlakuan A-D dan $\mathrm{K}$ suhu $25,05-26,50{ }^{\circ} \mathrm{C}$; pH 6,60-6,01; DO 3,56-2,50 ppm; CO2 0,61-0,78 ppm dan moniak 0,0508$0,087 \mathrm{ppm}$.

Kata kunci : Biodekomposer, transportasi, Ikan lele sangkuriang

\section{PENDAHULUAN}

Ikan lele sangkuriang (Clarias gariepinus var. sangkuriang) merupakan salah satu ikan konsumsi yang relatif mudah dipelihara karena dapat hidup pada perairan rendah oksigen, pertumbuhan cepat dan harga jual relative tinggi. Pertumbuhan ikan ini dapat dipacu dengan penggunaan benih yang berkualitas dan dapat diperoleh dari hatchery yang menerapkan sistem pembenihan yang baik. Ketika ikan ini didistribusikan kepada petani ikan adakala dalam jarak jauh, faktor kualitas air akan menyebabkan kematian yang tinggi.

Proses pengangkutan benih sering menyebabkan terjadinya penurunan kualitas dan peforma benih. Hal tersebut terkait dengan stress yang dialami ikan akibat adanya perlakuan saat packing dan kondisi lingkungan selama transportasi berlangsung. Adanya proses metabolisme ikan selama pengangkutan menyebabkan terjadinya penurunan kualitas air terutama peningkatan ammonia $\left(\mathrm{NH}_{3}\right)$ juga merupakan faktor yang menyebabkan terjadinya stress, puncaknya adalah kematian.

Biodekomposer merupakan kultur mikro organisme dalam bentuk zemogenik yang mampu mengaktifkan proses biokimiawi limbah organik dan mampu mempercepat proses dekomposisi (peruraian), menetralisir bau tidak sedap dan mampu memperbaiki subtract yang terdegradasi sehingga dapat mendorong terciptanya sistem perairan yang berkesinambungan (Lukitaningsih, 2009).

Oleh karena Biodekomposer mampu menjaga kualitas air, maka bahan tersebut berpeluang digunakan untuk mengatasi masalah penurunan kualitas air selama berlangsungnya proses transportasi. Oleh sebab itu diperlukan penelitian tentang efektifitas biodekomposer saat pengangkutan ikan Lele Sangkuriang (Clarias. Gariepinus Var. Sangkuriang ) dengan kepadatan tinggi pada transportasi tertutup untuk kebutuhan budidaya.

\section{METODE PENELITIAN}

Penelitian ini dilaksanakan selama masa percobaan transportasi ikan lele dilakukan selama 9-10 jam. Tempat penelitian dilaksanakan mengikuti jalur transportasi yakni Kelurahan Talang Bakung, Muara Sabak, dan Kota Jambi. Rancangan penelitian adalah Rancangan Acak Lengkap dengan 5 perlakuan dan 3 ulangan, perlakuan tersebut adalah: Perlakuan A: benih ikan lele 100 ekor/l air, B: benih ikan lele 200 ekor/liter air, C: benih ikan lele 400 ekor/liter air, D: benih ikan lele 600 ekor/liter air, Perlakuan K: benih ikan lele 100 ekor/liter air. Data yang diperoleh dari kegiatan penelitian ini dianalisis menggunakan analisa sidik ragam atau Anova. Jika berbeda nyata, maka dilanjutkan dengan uji Turkey pada taraf kepercayaan $5 \%$ dan semua parameter diamati diperkuat dengan analis deskriptif.

Ikan uji yang digunakan adalah benih ikan lele sangkuriang memiliki panjang rata-rata $2-3 \mathrm{~cm}$ dan berat rata-rata 0,34 gram yang berumur 1 bulan dari keturunan yang induk sama, benih yang digunakan dari benih yang sehat. Kebutuhan keseluruahan jumlah total benih selama percobaan adalah sebanyak 8400 ekor. 
Jurnal Akuakultur Sungai dan Danau Vol.1 No. 1 Tahun 2016 Hal 44 - 52

ISSN Online $2503-4766$

Sebelum dilakukan proses transportasi benih ikan lele sangkuriang (Clarias gariepinus var. sangkuriang) dilakukan kegiatan pengemasan. Tekniknya adalah ikan dimasukkan ke dalam kantong yang berisi air 2 liter yang sudah diberi 10 gram biodekomposer. Benih ikan lele sangkuriang (Clarias gariepinus var. sangkuriang) dihitung secara manual sesuai perlakuan tingkat kepadatan. Kemudian ikan dimasukkan kedalam kantong yang sudah berisi biodekomposer. Perbandingan air dan udara di dalam kantong 2:1. Kantong yang sudah siap diikat dengan karet.

Transportasi dilakukan dengan moda transportasi mobil, rute transportasi dimulai dari Kota Jambi, Muara Sabak, Kabupaten Tanjung Jabung Timur, pulang pergi selama 8 jam. Sebelum diangkut terlebih dahulu dilakukan pengecekan pertama yakni kualitas yang air meliputi suhu, $\mathrm{pH}, \mathrm{DO}, \mathrm{NH}_{3}, \mathrm{CO}_{2}$, dan ammonia, dan berikutnya adalah:

1. Sebelum diangkut dilakukan pengecekan pertama dan mulai berangkat dari Talang Bakung jam 12.45 s/d WIB.

2. Pengecekan ke dua jam 13.43 s/d WIB, dilakukan setelah 1 jam pertama (sampai ke Unbari) .

3. Pengecekan ke tiga jam $15.45 \mathrm{~s} / \mathrm{d}$ WIB, dilakukan setelah 2 jam ke dua (pengangkutan sampai simpang 35 atau simpang kiri)

4. Pengecekan ke empat jam $17.45 \mathrm{~s} / \mathrm{d}$ WIB, dilakukan setelah 2 jam ke tiga (pengangkutan sampai Jembatan Ma. Sabak Kab. Tanjung Jabung Timur)

5. Pengecekan ke lima jam 19.45 s/d WIB, dilakukan setelah 2 jam (Muara Jambi )

6. Pengecekan ke enam jam 21.31 s/d WIB. (sampai di Kota Jambi hingga akhir penghitungan jumlah kehidupan benih).

Untuk mendapatkan data saat dilaksanakan penelitian ini, maka di perlukan pengamatan parameter uji berikut yaitu:

\section{Tingkat Kelangsungan Hidup}

Tingkat kelangsungan hidup merupakan persentase dari jumlah ikan yang hidup dan jumlah ikan yang dimasukan dalam kantong selama penyimpanan rumus yang dimodifikasi (Goddard dalam Tarigan, 2014), dihitung sebagai berikut :

Keterangan :

$$
\text { SR }=\frac{N_{t}}{N_{0}} X 100 \%
$$

$\mathrm{SR}=$ Derajat kelangsungan hidup $(\%)$

$\mathrm{N}_{0} \quad$ = Jumlah ikan yang ditebar pada awal penelitian(ekor)

$\mathrm{N}_{\mathrm{t}} \quad$ = Jumlah ikan yang ditebar pada akhir penelitian (ekor)

\section{Kualitas Air}

Parameter kualitas air dan metodenya yang diamati dalam penelitian ini dapat dilihat pada Tabel 1, dibawah ini : 
Jurnal Akuakultur Sungai dan Danau Vol.1 No. 1 Tahun 2016 Hal 44 - 52

ISSN Online $2503-4766$

\begin{tabular}{|c|c|c|}
\hline No & Parameter & Alat Ukur \\
\hline 1 & Suhu & Thermometer \\
\hline 2 & $\mathrm{pH}$ & Kertas Lakmus \\
\hline 3 & DO & Titrasi (winkler) \\
\hline 4 & $\mathrm{NH}_{3}$ & Spektrofo Meter \\
\hline 5 & $\mathrm{CO}_{2}$ & Test Kit \\
\hline
\end{tabular}

\section{Tingkat Kelangsungan Hidup}

\section{HASIL DAN PEMBAHASAN}

Tingkat Kelangsungan hidup dan uji statistik ikan lele (Clarias. gariepinus Var. sangkuriang) di dalam wadah dan media transportasi selama 8 jam dengan pemberian biodekomposer dapat dilihat pada tabel 2 dibawah ini

Tabel 2. Tingkat Kelangsungan Hidup Ikan Lele (Clarias gariepinus var. sangkuriang) selama transportasi dengan kepadatan berbeda

\begin{tabular}{ccc}
\hline Perlakuan & $\begin{array}{c}\text { Rata-Rata } \\
\text { Kelangsungan } \\
\text { Hidup (\%) }\end{array}$ & Notasi Uji BNJ \\
\hline A (100 ekor/l + 10 gram Dekomposer ) & 91,17 & $\mathrm{a}$ \\
B (200 ekor/1 + 10 gram Dekomposer) & 85,87 & $\mathrm{a}$ \\
C (400 ekor/l + 10 gram Dekomposer) & 60,47 & $\mathrm{~b}$ \\
D (600 ekor/l + 10 gram Dekomposer) & 25,65 & $\mathrm{c}$ \\
K (100 Tanpa Dekomposer) & 18,58 & $\mathrm{c}$ \\
\hline Keterangan: Angka-angka yang diikuti oleh huruf yang berbeda & menunjukkan \\
perlakuan berbeda nyata pada Uji BNJ taraf 5\%. &
\end{tabular}

Berdasarkan tabel diatas terlihat bahwa masing-masing perlakuan memiliki tingkat kelangsungan hidup yang berbeda nyata, Tingkat perbedaan tingkat kelangsungan hidup terdapat pada perlakuan A, B, dan C. Sedangkan perlakuan D dan $\mathrm{K}$ ikan memiliki tingkat kelangsungan hidup terendah dalam waktu 8 jam. Untuk waktu media transportasi berkisar $8 \mathrm{jam}$. Hal ini menunjukkan bahwa selama waktu transportasi terdapat pengaruh dari perlakuan yang diberikan.

Tingkat kelangsungan ikan lele sangkuriang (Clarias gariepinus var. sangkuriang) selama perjalanan 8 jam padat tebar 600 ekor/l dalam kantong 2 liter air berarit sebayak 1200 ekor ikan perlakuan D dan K sangat rendah, hal ini disebakan oleh kualitas air yang menurun dari keadaan semula, terutama parameter terkait $\mathrm{CO} 2$ dan Amoniak. Tersisanya ikan lele ini yang masih hidup pada D $(25,56 \%)$ dan K $(18,58 \%)$ $\%$ pada ke dua perlakuan menunjukkan bahwa ikan lele sangkuriang termasuk ikan yang cukup kuat bertahan, hal ini disebabkan ikan lele sangkuriang mempunyai alat pernafasan tambahan. Ikan lele sangkuriang memiliki arboresent. Arborescent organ adalah alat pernapasan tambahan pada ikan lele untuk mampu bertahan hidup dalam kondisi oksigen yang minimum (Mahyudin 2008). Oleh karena itu ikan lele sangkuriang dapat hidup pada kepadatan yang tinggi.

Berdasarkan analisis statistik data diatas perlakuan padat tebar ikan pada media transportasi yang diberikan biodekomposer memberikan dampak yang signifikan, pada perlakuan $\mathrm{A}$ dan $\mathrm{B}$ dengan perlakuan $\mathrm{C}$ dan $\mathrm{D}$ tingkat kelangsungan tertinggi, masing- 
masing perlakuan kelulusan hidup sebesar A $(91,17 \%)$, B (85,87\%), C (60,47\%), D $(25,65 \%)$ dan $\mathrm{K}(18,58 \%)$. Hal ini disebabkan tingkat kelangsungan hidup dipengaruhi oleh pemberian biodekomposer, semakin tinggi dosis yang di dapat oleh individu ikan di sebabkan oleh tingkat kepadatan, semakin baik tingkat kelangsungan hidupnya. Biodekomposer pada perairan dapat memperbaiki kualitas air. Diduga biodekomposer memiliki kandungan jenis bakteri yang berfungsi dalam proses nitrifikasi untuk mendekomposisi atau mengurai bahan organik dalam perbaikan kualitas air. Bakteri nitrifikasi adalah bakteri-bakteri tertentu yang mampu menyusun senyawa nitrat dari amoniak yang berlangsung secara aerob. Menurut Holt et.al, 1994) dalam Abdillah (2009) bakteri yang termasuk bakteri nitrifikasi adalah Nitrosomonas dan Nitrobacter. Aktivitas bakteri pengoksidasi ammonium berkisar antara 0,120 - 1,612 ppm/hari, dan aktivitas pengoksidasi nitrit 0,024-0,132 ppm/hari (Nursyirwani, 2008).

Hasil pengamatan pada media uji pada perlakuan A dan B memiliki nilai oksigen masing-masing sebesar 3,56 ppm dan 3,50 ppm kelulusan yang tinggi, sedangkan pada perlakuan $\mathrm{C}$ dan $\mathrm{D}$ keduanya 2,50 ppm kelulusan hidup rendah. Wedemeyer (1966) menjelaskan bahwa kepadatan akan mempengaruhi kondisi kesehatan dan fisiologis ikan. Tingkat DO yang rendah dalam kolam dibarengi dengan nitrit yang tinggi dapat menurunkan transportasi oksigen kedalam darah yang dapat mengakibatkan stres dan kematian pada ikan (Boyd, 1990).

Tingkat kematian ikan lele sangkuriang selama waktu transportasi dengan kepadatan benih yang berbeda merupakan gambaran kebalikan tingkat kelulusan hidup yang dapat dilihat pada gambar 2 dibawah ini.

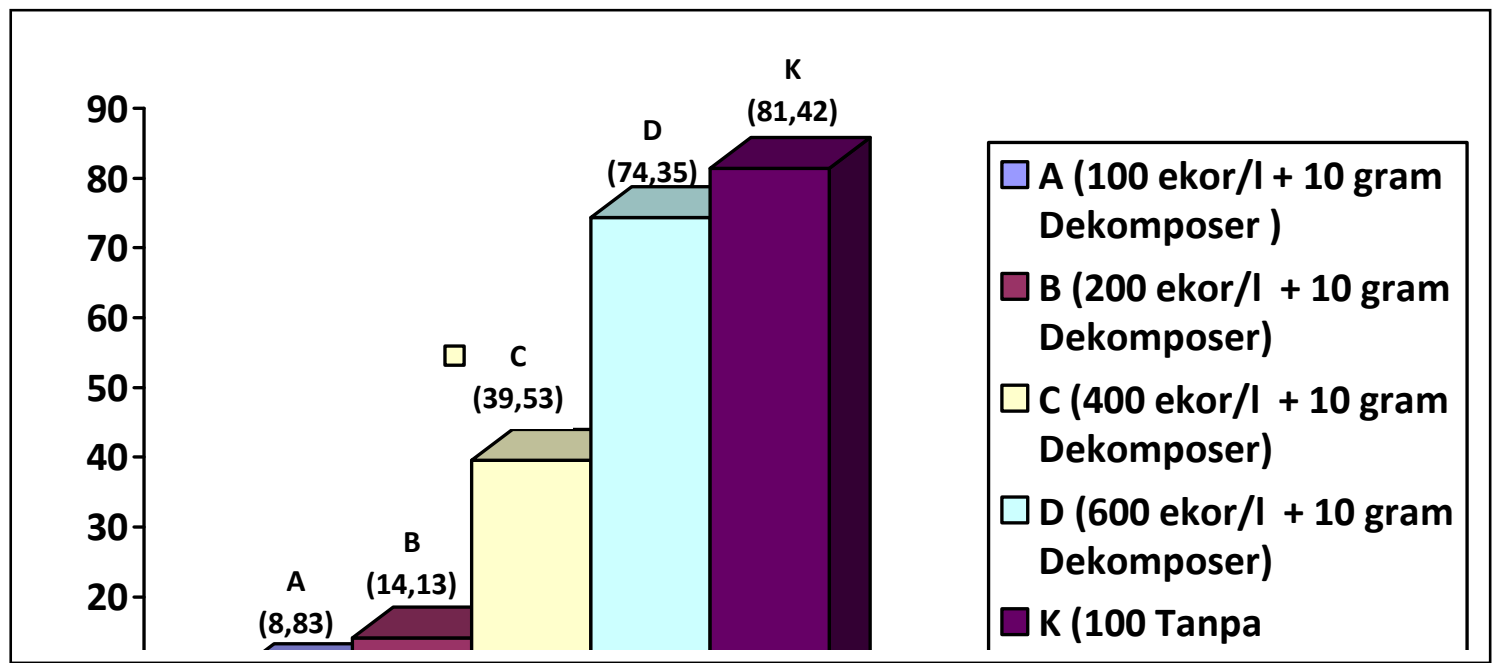

Gambar 1. Tingkat kematian ikan lele (Claria gariepinus var. sangkuriang) pada transportasi kepadatan yang berbeda dengan penambahan biodekomposer

Berdasarkan gambar diatas terlihat bahwa tingkat kematian ikan lele sangkuriang selama perlakuan mengalami peningkatan terutama pada perlakuan $\mathrm{C}$ dan $\mathrm{D}$ termasuk perlakuan kontrol $(\mathrm{K})$, dimana perlakuan dengan padat tebar tertinggi mengalami jumlah kematian ikan yang tinggi selama waktu pengamatan. Hal ini menunjukkan bahwa semakin tinggi kepadatan pada media trasnportasi maka kematian akan semakin tinggi kematian. Menurut Anto (2014) lama pengangkutan benih ikan patin dapat diangkut selama 10 jam dengan tingkat kelangsungan hidup mencapai 98,67\% dengan kematian 1,33\%\%, tingkatan kapadatan 300 ekor/ liter. Hal ini hampir 
Jurnal Akuakultur Sungai dan Danau Vol.1 No. 1 Tahun 2016 Hal 44 - 52

ISSN Online $2503-4766$

sama baiknya yang dilakukan dalam penelitian ini. Benih ikan lele yang dipaking 200 ekor/l dan 400 ekor/l yang hanaya diberi dekomposer 10 gram tampa oksigen dapat hidup 91,17 dan 85,87 (kematian 8,83\% dan 14,13\%). Jadi pemberian biodekomposer dapat menggantikan keberadaan oksigen yang biasa diberikan dalam pengangkutan benih ikan.

\section{Kualitas Air}

Kisaran nilai kualitas air selama proses transportasi dapat dilihat pada tabel 4 dibawah ini

Tabel 3. Kisaran kualitas air ikan lele percobaan selama penelitian

$$
\text { Parameter Kualitas Air }
$$

\begin{tabular}{ccccccccccc} 
Perlakuan & \multicolumn{9}{c}{ Sebelum transportasi } & \multicolumn{4}{c}{ Setelah Transportasi } \\
& $\begin{array}{c}\text { Suhu } \\
\left({ }^{\circ} \mathrm{C}\right)\end{array}$ & $\mathrm{pH}$ & $\begin{array}{c}\mathrm{DO} \\
(\mathrm{ppm})\end{array}$ & $\begin{array}{c}\mathrm{CO}_{2} \\
(\mathrm{ppm})\end{array}$ & $\begin{array}{c}\text { Amoniak } \\
(\mathrm{ppm})\end{array}$ & $\begin{array}{c}\text { Suhu } \\
\left({ }^{\circ} \mathrm{C}\right)\end{array}$ & $\begin{array}{c}\mathrm{pH} \\
(\mathrm{ppm})\end{array}$ & $\begin{array}{c}\mathrm{CO}_{2} \\
(\mathrm{ppm})\end{array}$ & $\begin{array}{c}\text { Amoniak } \\
(\mathrm{ppm})\end{array}$ \\
\hline $\mathrm{A}$ & 27,05 & 7,01 & 5,01 & 0,18 & 0,0453 & 25,05 & 6,50 & 3,56 & 0,61 & 0,0508 \\
$\mathrm{~B}$ & 27,05 & 7,01 & 5,01 & 0,18 & 0,0453 & 25,05 & 6,60 & 3,52 & 0,61 & 0,0818 \\
$\mathrm{C}$ & 27,05 & 7,01 & 5,01 & 0,18 & 0,0453 & 25,01 & 6,60 & 2,50 & 0,40 & 0,0865 \\
$\mathrm{D}$ & 27,05 & 7,01 & 5,01 & 0,18 & 0,0453 & 26,50 & 6,03 & 2,50 & 0,77 & 0,0866 \\
$\mathrm{~K}$ & 27,05 & 7,01 & 5,01 & 0,18 & 0,0453 & 26,41 & 6,01 & 2,45 & 0,78 & 0,0874 \\
\hline
\end{tabular}

Dalam budidaya ikan, kualitas air merupakan salah satu faktor yang penting untuk menentukan keberhasilan suatu usaha budidaya. Berdasarkan percobaan yang dilakukan, secara umum kondisi kualitas air menurun dengan bertambahnya tingkat kepadatan ikan.

Kandungan oksigen terlarut pada media transportasi benih ikan lele tergolong baik pada awal penelitian sebelum dilakukan transportasi. Akan tetapi kandungan oksigen terlarut menurun setelah proses transportasi dengan kandungan DO terendah terdapat pada perlakuan D 2,50 ppm dan perlakuan C 2,57 ppm. Penurunan DO disebabkan karena penggunaan oksigen yang tinggi oleh ikan lele pada saat transportasi. Penurunan kandungan oksigen tersebut juga menyebabkan ikan menjadi stres yang menyebabkan pada kematian. Hal tersebut sesuai dengan pernyataan Stickney (1979) bahwa pada kondisi padat penebaran ikan makin tinggi, oksigen terlarut semakin berkurang. Menurut Hemmingsen (1960) dalam Hapsari (2001), organisme berukuran kecil mengonsumsi oksigen lebih banyak per satuan waktu dan berat dari pada yang berukuran besar.

Selain kelarutan oksigen, suhu juga menjadi faktor penting bagi suatu usaha budidaya, karena metabolisme biota akuatik bergantung kepada suhu lingkungannya. Kisaran suhu selama transportasi berkisar antara $25,01-27,05^{\circ} \mathrm{C}$. Suhu sangat berkaitan erat dengan kelarutan oksigen, dimana pada suhu rendah ikan akan kesulitan mengambil oksigen (hipoxia) karena menurunnya detak jantung, dan proses osmoregulasi (Panjaitan, 2004). Perubahan suhu yang melebihi $3-4^{\circ} \mathrm{C}$ dalam waktu yang relatif singkat dan mengakibatkan kejutan suhu dan kematian ikan (Boyd, 1990)

Secara umum nilai $\mathrm{pH}$ berada pada kisaran 6,01-7,01. Nilai $\mathrm{pH}$ behubungan langsung dengan alkalinitas dan karbondioksida. Berdasarkan tabel 4 terlihat bahwa semakin tinggi padat tebar, nilai $\mathrm{pH}$ semakin menurun atau asam, hal ini menunjukkan 
Jurnal Akuakultur Sungai dan Danau Vol.1 No. 1 Tahun 2016 Hal 44 - 52

ISSN Online $2503-4766$

bahwa sekresi amoniak tidak maksimal sehingga timbunan tersebut akan menjadi toksik yang bersifat asam bagi organisme, hal ini diduga kapasitas penyangga yang tidak ada.

Karbondioksida dalam air pada umumnya merupakan hasil respirasi dari ikan dan fitoplankton. Kadar $\mathrm{CO}_{2}$ lebih tinggi dari $10 \mathrm{ppm}$ diketahui menunjukkan bersifat racun bagi ikan, beberapa bukti menunjukkan bahwa karbondioksida berfungsi sebagai anestesi bagi ikan. Kadar karbondioksida tinggi juga menunjukkan lingkungan air yang asam meskipun demikian karbondioksida diperlukan sebagai buffer (O-Fish, 2003). Kandungan $\mathrm{CO}_{2}$ bebas berkisar antara 13,73-23,60 ppm. Kadar $\mathrm{CO}_{2}$ bebas lebih dari 25 mg/l sudah membahayakan kehidupan ikan (NTAC, 1968 dalam Akrimi dan Gatot, 2002). Swingle (1968) menyatakan bahwa kandungan $\mathrm{CO}_{2}$ bebas $12 \mathrm{ppm}$ menyebabkan ikan stress dan bila kadar $\mathrm{CO}_{2}$ bebas mencapai $30 \mathrm{ppm}$, beberapa jenis ikan akan mati. Menurut O-Fish (2003), secara umum dapat dikatakan bahwa $\mathrm{CO}_{2}$ terlarut dalam akuarium dengan kepadatan sedang akan berada pada selang 1-3 ppm. Untuk akuarium tanaman kadar karbondioksida sebesar 15 ppm merupakan nilai yang ideal.

Padat penebaran berpengaruh terhadap laju oksidasi amoniak. Dekomposisi metabolit dan sisa pakan yang meningkat akan meningkatkan konsentrasi amoniak di dalam sistem, sehingga mendorong meningkatnya laju oksidasi amoniak. Kandungan amoniak yang diperoleh pada awal sebelum ikan ditransportasikan sebesar 0,0453 ppm, sedangkan setelah ditransportasikan nilai amoniak berkisar antara berkisar antara 0,050,08 ppm. Berdasarkan tabel 4 tersebut terlihat bahwa nilai amoniak meningkat seiring meningkatnya padat tebar ikan. Meningkatnya amoniak selama pemeliharaan dikarenakan semakin meningkatnya bahan buangan metabolisme seiring meningkatnya padat penebaran. Bahan buangan tersebut cenderung asam sehingga mempengaruhi kandungan amoniak yang semakin meningkat.

\section{KESIMPULAN}

Perlakuan kepadatan benih yang berbeda dalam media biodekomposer 10 gram selama transportasi sistem tertutup memberikan pengaruh yang nyata terhadap tingkat kelangsungan hidup benih ikan lele (Clarias gariepinus var.sangkuriang) Transportasi benih ikan lele dengan kepadatan 100 ekor/liter air (Perlakuan A) merupakan perlakuan terbaik, karena memiliki tingkat kelangsungan hidup yang tinggi sebesar $(91,17 \%)$,dan kematian $(8,83 \%)$. Tingkat kelulusan hidup terendah pada perlakuan $\mathrm{D}(25,65)$ dan $\mathrm{K}$ $(18,58)$

\section{DAFTAR PUSTAKA}

Anonim. 2002 "Petunjuk Praktis Pengendalian Hama dan Penyakit Ikan" Pengangkutan Benih Ikan Jarak Jauh Dengan Oksigen

Anto, 2014. Pengangkutan Benih Ikan Jarak Jauh Dengan Oksigen. https://www.banyudadi.com/pengangkutan-benih-ikan-jarak- jauh- denganoksigen

Anas, Iswandi. 1993. Pupuk Hayati (Biofertilizer). Bogor: Laboratorium Biologi Tanah, Jurusan Tanah, Fakultas Pertanian, Institut Pertanian Bogor.

Berka.R. 1986. The transport of live fish EIFAC Tech. Pap.No. 48. p.52Froces.

Boyd, C. E. 1990. Water Quality in Ponds for Aquaculture. Auburn University. Alabama. 482 p.

Brandao F R, Gomes L C, Chagas E C, Araujo L D, Silva A L F, Silva C R. 2004. Stocking density of matrinxã juveniles during second growth phase in cages. Fish culture performance in the tropics, Manaus 
Jurnal Akuakultur Sungai dan Danau Vol.1 No. 1 Tahun 2016 Hal 44 - 52

ISSN Online $2503-4766$

Chet I (Ed.). 1987. Innovative Approaches to Plant Diseases Control. John Wileyand Sons, A Wiley-Interscience Publication, USA. pp. 11-210.

Cook RJ, Baker KF. 1989. The Nature on Practice of Biological Control of Plant Pathogens. ABS press, The American Phytopathological Society, St. Paul, Minesota $539 \mathrm{p}$.

Djadmika. P.H Farlina, Sugiarti. E, 1986. Usaha budidaya Ikan Lele, CV. Simplex, Jakarta

Effendi, Nasser (2013) Metode Biologi Perikanan. Yayasan Dewi Sri. Bogor

Fauziah, Miranti, S. Agustiawan. 2011 "Pemingsanan Ikan Mas (Cyprinus carpio) dengan Menggunakan Ekstrak Tembakau, Ekstrak Mengkudu dan Ekstrak Cengkeh'’I. Gunawan 2013 Penebar Swadaya. Jakarta

Hook,2000Fish and Marine Sciences 2 (1):29_36,2010. http://repository.ipb.ac.id/bitstr eam/handle/123456789/44048/PKM\%20AI\%20TRANSPORT.pdf?sequence=2

Harman GE. 1998. Trichoderma spp. Proc. Am. Acad. Sci. USA. http://www.nyaseas.cornel.edu/end/biocontrol/pahogens/trichoderma.html

Hapsari A. 2001. Pengaruh salinitas 3 ppt dan kesadahan moderat terhadap daya kerja filter pada sistem resirkulasi untuk budidaya ikan mas koki (Carassius auratus Linnaeus). [skripsi]. Bogor. Program Studi Budidaya Perairan, Fakultas Perikanan dan Ilmu Kelautan, IPB

Hepher, B. dan Y. Pruginin. 1981. Commercial Fish Farming with Special Reference to Fish Culture in Israel. John Willey and Sons, New York. 261 hal.

Kusnadi, dkk. 2013 Peran Mikroorganisme Dalam Pembusukan Sampah Organik lewat EmailBlogThis!Berbagi ke TwitterBerbagi ke Facebook

Khairuman dan Khairul Amri.2009.Buku Pintar Budidaya 15 Ikan Konsumsi. AgroMediaPustaka:Jakarta

Lukito A.M. 2002. "Lele Ikan Berkumis Paling Populer” Agromedia. Jakarta

Lukitaningsih, D. 2009 http://luki2blog.wordpress.com/2009/03/04/decomposer- biosuper-active/ Decomposer "Bio Super Active “"

Lukito .2008. Pembenihan Ikan Lele Sangkuriang Sunarma 2011 (Iii). Indonesi Fish Breeding And Aquaculture Development Practitioner.

Nasser T.M, 2013. "Tips Pengemasan Benih Ikan Untuk Dikirim”

$\begin{array}{llll}\text { Rifai } & 1969 & \text { Trichoderma Pseudokoningii Mycobank. } 2000\end{array}$ http://www.mycobank.org/BioloMICSServer.aspx?Link=T\&Rec=340304.

Rinto.2012 “Transportasi Ikan Hidup” Berka, 1986 More Sharing ServicesShare

Pizzi, A. 1983. Tanin-based wood adhesive. Dalam Pizzi A (ed.) Wood adhesive Technology. New York, Blackwell Dekker.

Santosa, Dwi Andreas. 1989. Teknik dan Metode Penelitian Mikorisa VesikularArbuskular.

Simanjutak, R,H. 1989. "Pembudidayaan Ikan Lele Sangkuriangdan Dumbo”. Bharatara.

Steel, G. D dan J. H. Torrie, 1981. Prinsip-prinsip dan Prosedur Statistika. Terjemahan PT. Gramedia Pustaka Utama. Jakarta. 747 halaman.

Stikcney, R. R. 1979. Principal of Warmwater Aquacultur. John Wiley and Sons. Inc. A wiley-Interscience Publication. New York. UAS. 375 halaman.

Susanto, H. 2007. "Budidaya Ikan Dipekarangan." Penebar Swadaya, Jakarta

Swingle. 1968. Standardization of chemical analysis for water and pond muds. FAO Fish Rep. 44(4): 379-406. 
Jurnal Akuakultur Sungai dan Danau Vol.1 No. 1 Tahun 2016 Hal 44 - 52

ISSN Online $2503-4766$

Tawan, S. 2013. Decomposer ” Bio Super Active “

Wedemeyer GA. 1996. Physiology of Fish in Intensive Culture System. USA: Chapman and Hall.

Yani. A. 2012“Tinjauan Budidaya Ikan Lele Sangkuriang (Clarias Sp) Serta Analisis Pendapatannya" Baturaja.

Yulneriwarni, 2008. Klasifikasi Bakterim (Mikrobiologi). http://maliyuri. blogspot. com/2008/03/02-klasifikasi-bakteri-mikro-dasar. html 